tually provide indexes to quantitative and qualitative data pertaining to gravity, magnetism, seismicity, volcanoes, tsunamis, conductivity, layer thickness, acoustics, radioactivity, heat flow, and reflectivity.

Bathymetric data from bathythermographs will eventually include tracklines, PDR traces, fathograms, discrete sonic soundings, wire soundings, index of roughness, and slope. Bottom and sedi- ment and rock data will include the physical properties, size analysis, mineralogy, geochemical properties, engineering aspects, paleontology, and bottom photographs.

The growing international interest in oceanography has led to greater participation of foreign countries, which are now supplying data to the center, as well as drawing on its wealth of rapidly accumulating information.

\title{
U.S. Office of Education 1962-63 Collsge and University Library Statistics
}

FOR THE PAST three years the Office of Education has collected basic data on the book collection, staff, expenditures and salaries of college and university libraries. This information was published as Institutional Data for 1959-60, 1960-61 and 1961-62 and an Analytic Report for 1959-60. The analytic reports for 1960-61 and 1961-62 will be released in one volume which is nearing completion. Whereas Institutional Data provide information about individual institutions, arranged by states, the Analytic Report contains summaries by type of academic institution and size of enrollment.

For the first time, last year, over a dozen state libraries cooperated with the Library Services Branch in the distribution and collection of questionnaires. Thanks to this collaboration, the returns in these states were substantially higher than in the nonparticipating states. As a result, this year all fifty states were invited to participate in this cooperative effort and forty-eight state library agencies are assisting the Office of Education in this study. In Alabama and North Dakota, the academic libraries are being contacted directly. The 1962-63 forms were mailed out between August 19 and 21 .

In response to requests for earlier releases of statistical data from the Association of College and Research Libraries and individual librarians, it was decided to ask academic libraries to return their forms as early as possible but not later than September 30,1963 to the state agencies or, in the case of Alabama and North Dakota institutions, to the U.S. Office of Education.

In January 1964 the office will publish the institutional data for all libraries which have met the September 30 deadline. The second deadline for inclusion in the Analytic Report is set for December 1, 1963, to assure publication by the summer of 1964 .

Based on past experience it is hoped that at least 60 per cent of academic libraries will be included in the current listing of institutional data. To speed up the release of the Analytic Report the Library Services Branch cannot make available a more complete listing of 1962-63 institutional data.

Questions were added this year on interlibrary loan transactions and the hourly wage rate paid to student assistants. The information concerning salaries of full time personnel is requested in a simpler and more specific manner than previously.

It is expected that the procedures for the current survey will result in faster and better service to administrators, librarians and others concerned with academic library service. Better coordination and less duplication in the collection and analysis of academic library statistics should also result.

If this year's effort succeeds, it could be said that a nationwide academic library statistics system has been established.-Frank L. Schick, Assistant Director, Library Services Branch. 